\title{
Expression of Novel Interleukin 2 Binding Molecules and Their Functional Roles in Human B Cell Differentiation
}

Toshio Tanaka, Osamu Saiki, Satoru Doi, Masaki Suemura, Shigeru Negoro, and Susumu Kishimoto

Third Department of Internal Medicine, Osaka University, Fukushima-ku, Osaka, 553, Japan

\begin{abstract}
Expressions and functional roles of novel IL-2 binding molecules $(\mathbf{p} 70,75)$ in the differentiation of $B$ cells into Ig secreting cells were explored by using human several B cell lines and tonsillar B cells. Affinity-crosslinking studies revealed that five of nine B cell lines expressed p70 and p75 without detectable Tac antigen (p55) expression and the expression was associated with B cell maturation. In tonsillar B cells, small high-density B cells did not express $\mathbf{p 7 0}$ and p75, whereas large low-density $B$ cells, which were thought to be activated in vivo, expressed them. Binding assays of radiolabeled IL-2 showed that the affinity of these molecules was intermediate ( $\mathrm{kD}=1-3 \mathrm{nM}, 700-3,000$ sites/cell). Furthermore, high concentrations of IL-2 $(>100 \mathrm{U} / \mathrm{ml})$ induced Ig productions in large $B$ cells and two of five cell lines. These results taken together suggest that B cells may express novel IL-2 binding molecules, associated with $B$ cell differentiation and differentiate into Ig secreting cells by IL-2 through novel IL-2 binding molecules.
\end{abstract}

\section{Introduction}

IL-2 is a T cell-derived lymphokine with growth and differentiation promoting activities on responding cell populations through its interaction with high affinity IL-2 receptor (IL-2R) ${ }^{1}$ (1-3). Recently, the existence of novel IL-2 binding molecules $(p 70,75)$ differed from Tac antigen (p55) has been demonstrated in T-cells, NK cells and a B cell line and high affinity IL-2R is thought to be made up of p70, 75, and p55 (4-8). Furthermore, it is suggested that $\mathrm{p} 70,75$ are responsible for signal transduction of IL-2 (9-13).

In artificially activated B cells and some B cell lines, it is generally accepted that IL-2 induces proliferation or Ig secretion through high affinity IL-2 receptor (14-17), whereas evidences that IL-2, in some circumstance, may provide signals in B cells lacking Tac antigen are also accumulating $(18,19)$. However, the precise characterization of this mechanism remains unknown.

Address reprint requests to Dr. Saiki, The Third Department of Internal Medicine, Osaka University, Fukushima-Ku, Osaka, 553, Japan.

Received for publication 27 July 1987 and in revised form 19 November 1987.

1. Abbreviations used in this paper: DSS, disuccinimidyl suberate; IL-2R, IL-2 receptor; PK-C, protein kinase C; PMA, phorbol myristate acetate; rBSF2, recombinant B cell stimulating factor 2; SAC, Staphylococcus aureus Cowan 1.

J. Clin. Invest.

(C) The American Society for Clinical Investigation, Inc.

0021-9738/88/07/0316/06 \$2.00

Volume 82, July 1988, 316-321
Here, we show the existence of p70, 75 in human several B cell lines and large low-density B cells, which are thought to be activated in vivo, and the differentiation of B cells by IL- 2 and discuss the mechanism of B cell differentiation by IL- 2 .

\section{Methods}

Cell line. Human B cell lines, NALM6, Daudi, Raji, Ramos, SKW6-4, CESS, ARH-77, U266, and RPMI 8866 cells have been maintained in RPMI 1640 (Gibco, Grand Island, NY) containing 10\% FCS (Sterile Systems, Logan, UT), $2 \mathrm{mM}$ L-glutamine, $100 \mu \mathrm{g}$ streptomycin and $100 \mathrm{U}$ penicillin/ml (culture medium).

$B$ cell preparation. Tonsillar B cells were obtained by the following steps. Tonsillar mononuclear cells were allowed to rosette with S-(2 aminoethyl)-isothiouronium bromide-treated sheep erythrocytes twice to remove $T$ cells and nonrosetting cells were incubated on plastic dishes for $2 \mathrm{~h}$ at $37^{\circ} \mathrm{C}$ to remove monocytes. Nonadherent cells were further purified by treatments with OKT3 and OKM1 monoclonal antibodies and complement. Small high density and large low density B cells were separated by centrifugation on Percoll density gradients (20). The fractions recovered at the interface between 60 and $70 \%$ Percoll solution were small high density B cells and large low-density B cells were obtained from the fractions between 50 and 55\% Percoll solution. The resulting small high density $B$ cells and large low density B cells contained less than $0.2 \%$ contaminating $T$ cells and monocytes, and consisted of more than $98 \%$ B-cells, as assessed by indirect immunofluorescence using OKT3, OKM1, and B1 monoclonal antibodies. The possible contamination by $\mathrm{T}$ cells in these populations were also determined functionally. These B cells do not respond when cultured with PWM.

Radiolabeled IL-2 binding assay. rIL-2 was iodinated with $\mathrm{Na}^{125} \mathrm{I}$ by the chloramine $\mathrm{T}$ method and the specific activity of ${ }^{125} \mathrm{I}$-labeled IL-2 ( $\left.{ }^{125} \mathrm{I}-\mathrm{IL}-2\right)$ was $1.5-2.4 \times 10^{4} \mathrm{cpm} / \mathrm{ng}$. IL-2 binding assay was performed as reported previously (21). Briefly, cells $\left(2 \times 10^{6}\right)$ were incubated with serial dilutions of ${ }^{125} \mathrm{I}-\mathrm{IL}-2$ in a total volume of $150 \mu \mathrm{l}$ RPMI 1640 containing $0.02 \% \mathrm{NaN}_{3}, 1 \%$ BSA and $25 \mathrm{mM}$ Hepes for 1 $\mathrm{h}$ at $4^{\circ} \mathrm{C}$. The mixtures were then centrifuged, the supernatants were removed, and the precipitated cells were resuspended in $100 \mu \mathrm{l}$ of PBS. The cell suspensions were layered on $750 \mu$ l of RPMI 1640 containing $1 \mathrm{M}$ sucrose, $0.02 \% \mathrm{BSA}$, and $0.02 \% \mathrm{NaN}_{3}$ and were centrifuged at $12,000 \mathrm{rpm}$ for $3 \mathrm{~min}$ at $4^{\circ} \mathrm{C}$. The radioactivities of the resulting supernatants and cell precipitates were then counted. The specific binding of ${ }^{125} \mathrm{I}-\mathrm{IL}-2$ to cells was calculated by subtracting the count of the sample containing excess unlabeled IL-2 (100-fold) for competitive binding from observed count.

Gel-electrophoresis of IL-2 binding molecules. ${ }^{125}$ I-IL-2 was crosslinked to IL-2 binding molecules as previously described (4) with minor modifications. Briefly, $10^{7}$ cells were resuspended with $400 \mu \mathrm{l}$ of RPMI 1640 containing $25 \mathrm{mM}$ Hepes and $1 \%$ BSA and incubated with $10 \mathrm{nM}$ or $2 \mathrm{nM}{ }^{125} \mathrm{I}-\mathrm{IL}-2$ for $1 \mathrm{~h}$ at $4^{\circ} \mathrm{C}$. After incubation, cells were pelleted at $400 \mathrm{~g}$ and resuspended in $5 \mathrm{ml}$ of PBS, pH 8.3, containing 1 $\mathrm{mM} \mathrm{MgCl}$. Then, disuccinimidyl suberate (DSS) was added to the cell suspension at a final concentration of $0.3 \mathrm{mM}$, cells were tumbled at $4^{\circ} \mathrm{C}$ for $20 \mathrm{~min}$ and $5 \mathrm{ml}$ of $10 \mathrm{mM}$ Tris and $1 \mathrm{mM}$ EDTA was added. Cells were pelleted at $400 \mathrm{~g}$ and extracted in $50 \mu \mathrm{l}$ of $300 \mathrm{mM} \mathrm{NaCl}, 50$ $\mathrm{mM}$ Tris and $0.5 \%$ NP40, pH 7.4. Postnuclear lysates were boiled in SDS and analyzed on SDS-PAGE under reducing condition. 
Immunoglobulin production. Several B cell lines $\left(10^{3}-10^{4}\right.$ cells/ well), large low density and small high density B cells $\left(10^{5}\right.$ cells/well) were cultured with various concentrations of rIL-2, whose specific activity was $1.8 \times 10^{7} \mathrm{U} / \mathrm{mg}$, or recombinant $B$ cell stimulating factor 2 (rBSF2) (kindly provided by T. Kishimoto and T. Hirano) for 4 or $5 \mathrm{~d}$ in $200 \mu \mathrm{l}$ culture medium. The concentrations of $\mathrm{Ig}$ were measured by ELISA as described before (22). To exclude the possibility of B cell differentiation by IL-2 through high affinity IL-2R, large B cells were incubated with various doses of IL-2 in the presence of H-31 monoclonal antibody ( $50 \mu \mathrm{g} / \mathrm{ml}$ ) (kindly provided by $\mathrm{K}$. Sugamura), which recognized Tac antigen and inhibited the binding of IL-2 to Tac antigen (13).

Proliferative response. Cells ( $10^{5} /$ well) were incubated with IL- 2 for $3 \mathrm{~d} .0 .4 \mu \mathrm{Ci}$ of $\left[{ }^{3} \mathrm{H}\right]$ thymidine $(18.2 \mathrm{Ci} / \mathrm{mM})$ was added for the last $6 \mathrm{~h}$. Cells were harvested and washed on glass filters and $\left[{ }^{3} \mathrm{H}\right]$ thymidine incorporation was measured in a liquid scintillation counter.

\section{Results}

Several B cell lines displayed intermediate affinity $I L-2 R(p 70$, $p 75)$. Previous studies demonstrated that some B cell lines or artificially activated B cells expressed high affinity $\left(K_{d}\right.$ $=10-200 \mathrm{pM})$ and low affinity $\left(K_{\mathrm{d}}=10-20 \mathrm{nM}\right)$ IL-2R (14-17). Recently the existence of novel IL-2 binding molecules $\left(K_{d}=0.7-2 \mathrm{nM}\right)$ has been demonstrated in T- and NKlike cell line and a B cell line $(4-8,23)$. Therefore, we reexamined the existence of IL- 2 binding molecules in B cells by using nine B cell lines, which included from a pre-B cell line to Ig secreting cell lines. Radiolabeled IL-2 binding assays revealed that low affinity IL-2R $\left(K_{d}=12 \mathrm{nM}\right.$, sites/cell $\left.=1,072\right)$ was detectable in Ramos cells and intermediate affinity IL-2R $\left(K_{d}\right.$ $=1-3 \mathrm{nM}$, sites/cell $=700-2,500)$ were detectable in five $\mathrm{B}$ cell lines (SKW6-4, CESS, ARH-77, U266, and RPMI 8866), whereas IL-2R were undetectable in NALM6, Daudi, and Raji cells (Table I).

We examined the molecular weights of IL- 2 binding molecules by the affinity crosslinking method as described in Methods. Fig. 1 shows that one band $(70 \mathrm{kD})$ was migrated in
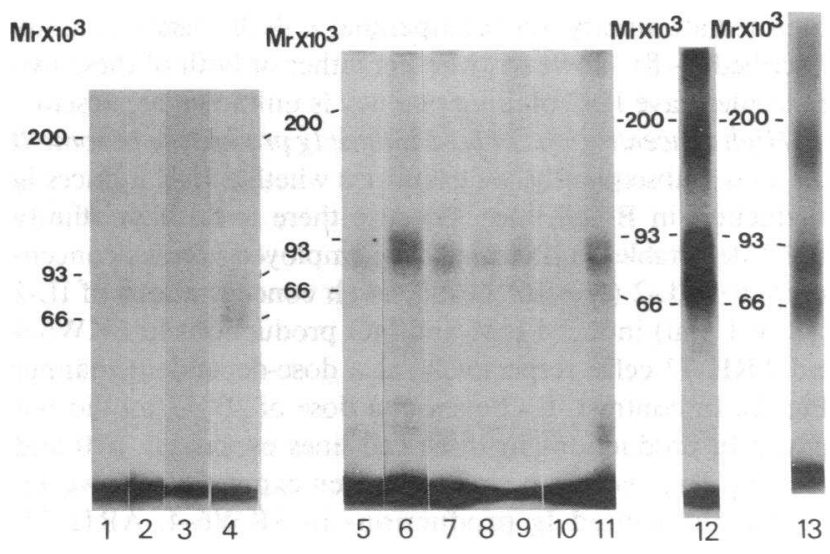

Figure 1. Affinity-crosslinking study in several B cell lines and normal B cells. NALM6 (lane 1), Daudi (lane 2), Raji (lane 3), Ramos (lane 4), SKW6-4 (lane 5), CESS (lane 6), ARH-77 (lane 7), U266 (lane 8), RPMI 8866 (lane 9), small high-density B-cells (lane 10), large low-density B-cells (lane 11$)\left(10^{7}\right.$ cells) were incubated with 10 $\mathrm{nM}{ }^{125} \mathrm{I}-\mathrm{IL}-2$ for $1 \mathrm{~h}$ at $4^{\circ} \mathrm{C}$. PHA-stimulated T cells (lane 12) and SAC-stimulated B cells (lane 13$)\left(10^{7}\right.$ cells) were also incubated with $2 \mathrm{nM}^{125} \mathrm{I}-\mathrm{IL}-2$ and crosslinkages were carried out.

Ramos cells (Fig. 1, lane 4), which expressed low affinity IL-2R and that two bands ( 85 and $90 \mathrm{kD}$ ) were migrated in five cells expressing intermediate affinity IL-2R (Fig. 1, lane 5-9). However, there was no detectable IL-2 binding molecule in NALM6, Daudi, and Raji cells (Fig. 1, lanes 1-3). The presence of excess monoclonal antibody to Tac antigen (H-31) inhibited the appearance of $70 \mathrm{kD}$ band but did not inhibit that of $85-$ and $90-\mathrm{kD}$ bands, which were p70 and p75 molecules, calculated to be crosslinked to $15 \mathrm{kD}$ IL-2, suggesting that $70 \mathrm{kD}$ was associated with Tac antigens (p55) (data not shown). Furthermore, excess unlabeled IL-2 inhibited the binding of ${ }^{125} \mathrm{I}-\mathrm{IL}-2$ to these bands. The results that novel IL-2 binding molecules ( $p 70$, P75) have IL-2 binding potency of

Table I. Scatchard Plot Analysis of IL-2R

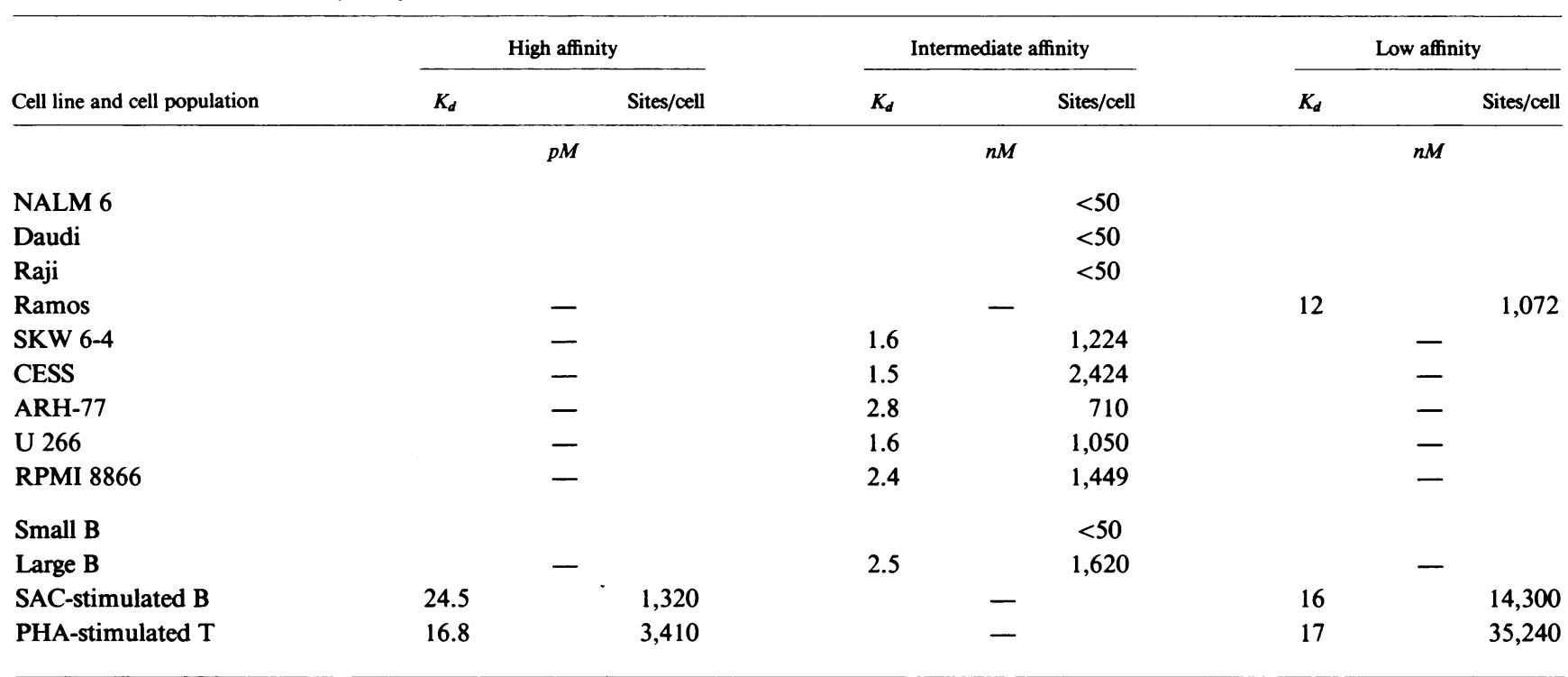

Cells $\left(2 \times 10^{6}\right)$ were incubated with serially diluted ${ }^{125} \mathrm{I}-\mathrm{IL}-2$ for $1 \mathrm{~h}$ at $4^{\circ} \mathrm{C}$ and the radioactivities of separated supernatants and precipitated cells were counted. Nonspecific binding was estimated by adding excess unlabeled IL- 2 in the binding assay. 
intermediate affinity were comparable with the results recently described (5-8). However, whether either or both of these two molecules have IL-2 binding potency is unknown at present.

High concentrations of $I L-2$ induce Ig production in some $B$ cell lines. Subsequently, we examined whether IL-2 induces Ig production in B cell lines. Because there is no high affinity IL-2R detectable on these cells, we employed various concentrations of IL-2 $\left(1-10^{4} \mathrm{U} / \mathrm{ml}\right)$. High concentrations of IL-2 (> $100 \mathrm{U} / \mathrm{ml}$ ) induced IgM and IgG productions in SKW6-4 and ARH-77 cells, respectively, at a dose-dependent manner (Fig. 2). In contrast, IL-2 even at a dose of $10^{4} \mathrm{U} / \mathrm{ml}$ did not induce Ig productions in three cell lines expressing p70 and p75, and Ramos cells with Tac antigen expression. However, r-BSF2 augmented Ig productions in SKW6-4, ARH-77, CESS, and U266 cells, irrespective of isotypes of Ig produced.

High concentrations of $I L-2$ induce Ig production in large $B$ cells through p70, 75 molecules. In vitro artificially activated B cells are known to express high affinity IL-2R and physiological concentrations of IL-2 induce growth and differentiation of B cells (14-17), whereas whether B-cells express IL-2R in vivo remains unknown. We obtained small high-density and large low-density $B$ cells by negative selection technique to avoid as far as possible impairment of B cell functions. We examined whether these populations were induced to differentiate into Ig secreting cells by IL-2. Five of seven experiments showed a similar pattern despite the fact that the magnitude of the response was variable from experiment to experiment. A representative result is shown in Fig. 3. High concentrations of IL-2 (above $100 \mathrm{U} / \mathrm{ml}$ ) induced $\mathrm{Ig}$ productions in large B cells. In contrast, small B cells did not respond to IL-2 at any concentration. The response of large B cells to IL-2 was not inhibited by excess $\mathrm{H}-31$ (data not shown). SAC-stimulated B cells were induced to produce Ig by even low doses of IL-2. Radiolabeled binding and affinity crosslinking studies revealed that these large B cells expressed intermediate affinity IL-2R $\left(K_{d}=2.5\right.$ $\mathrm{nM}$, sites/cell $=1,620$ ) and p70, 75 molecules but small $\mathrm{B}$ cells did not express them (Table I and Fig. 1, lanes 11 and 10).

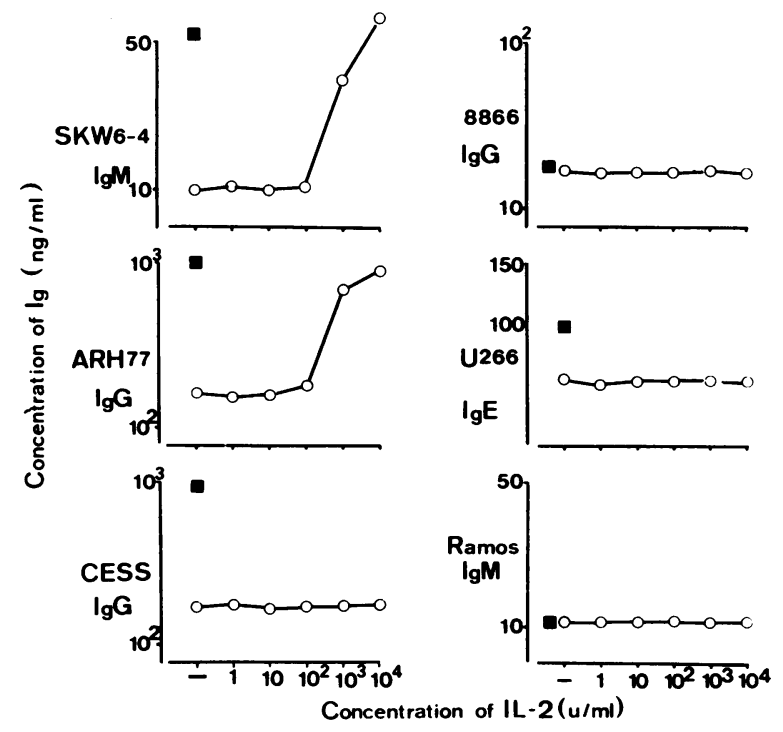

Figure 2. Induction of Ig productions in B cell lines by IL-2. Cells $\left(10^{4} /\right.$ well except for $10^{3} /$ well in U266) were incubated with various concentrations of IL-2 (0) or recombinant BSF2 $(10 \mathrm{U} / \mathrm{ml})(\boldsymbol{a})$ for 4 $\mathrm{d}$ and Ig productions were assayed by ELISA.
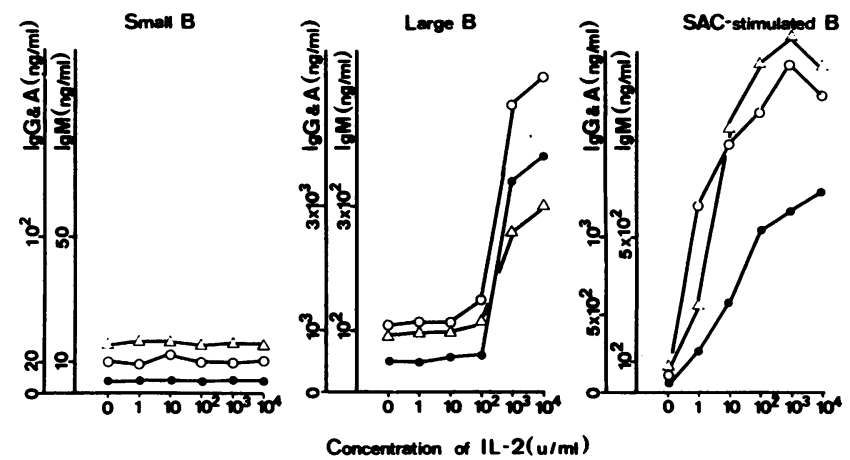

Figure 3. Induction of Ig productions in tonsillar B cells by IL-2. Small high density B cells, large low density B cells and stimulated Bcells $\left(10^{5} /\right.$ well), which had been cultured with $0.001 \%$ SAC for $2 \mathrm{~d}$, were incubated with IL-2 for $5 \mathrm{~d}$ and IgM (๑), IgG (0), and IgA productions $(\Delta)$ were assayed by ELISA.

SAC-stimulated B-cells had low $\left(K_{d}=16 \mathrm{nM}\right.$, sites/cell $=14,300)$ and high affinity IL-2R $\left(K_{d}=24.5 \mathrm{pM}\right.$, sites/cell $=1,320$ ), and expressed not only $\mathbf{p} 70,75$ but also Tac antigen (p55) in addition to a broad band of 160-200 kD (Table I, Fig. 1 , lane 12), although a precise characterization of this broad band remains unknown $(4,7,8)$.

However, two of seven experiments indicated that IL-2 at a dose induced IgM productions in large B cells but maximal induction was obtained at a high dose (Fig. 4). In the presence of H-31, which completely blocked the binding of IL-2 to Tac antigen (13), the induction by low doses of IL-2 was inhibited and high concentrations of IL-2 were required for B cell differentiation (Fig. 4). The pattern of IgG and IgA productions was similar to that of IgM (data not shown). Although in flow cytometric analysis by using $\mathrm{H}-31$ there are few detectable Tac antigen positive cells, affinity crosslinking study revealed the existence of p55 in addition to more p70, p75 molecules and binding study indicated the existence of intermediate affinity $\left(K_{d}=2.2 \mathrm{nM}\right.$, sites/cell $\left.=1,100\right)$ and high affinity IL-2R $\left(K_{d}\right.$ $=24 \mathrm{pM}$, sites $/$ cell $=300$ in these large $B$ cells (data not shown). These two experiments suggested that in some condition of host immune status some large $B$ cells may express high affinity IL-2R.

IL-2 induces Tac antigen expression in large $B$ cells. Recently, it was reported that high concentrations of IL-2 induced Tac antigen through p70, 75 in unstimulated T, NK, and LAK cells (10-12). We examined whether this induction occurred in large B cells. Large B cells were incubated with IL-2 $(2 \mathrm{nM})$ for $2 \mathrm{~d}$, washed extensively, incubated at $37^{\circ} \mathrm{C}$ for

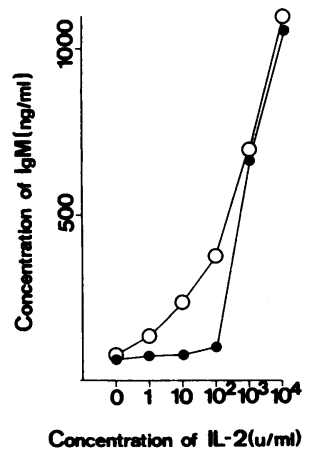

Figure 4. Induction of IgM productions in large B cells by IL-2 in the presence or absence of H-31. Large low density B cells were cultured with various doses of IL-2 in the presence ( $\bullet$ ) or absence (0) of $\mathrm{H}-31(50 \mu \mathrm{g} / \mathrm{ml})$ for $5 \mathrm{~d}$ and IgM productions were assayed by ELISA. The pattern of IgG and IgA productions was similar to that of IgM. 
$4 \mathrm{~h}$ and affinity crosslinkages were carried out. Fig. 5 shows that IL-2 also induced Tac antigen expression in these populations, indicating that large $B$ cells might express Tac antigen that could associate with p70, 75 to form high affinity IL-2R. However, Northern blot analysis and affinity crosslinking study revealed that SKW6-4 cells were not induced to express Tac antigen by IL-2 (data not shown).

Large $B$ cells proliferate in response to $I L-2$. Finally, we examined the proliferative response to IL-2 in B cells. A representative result of three experiments showed in Table II. Increase of $\left[{ }^{3} \mathrm{H}\right]$ thymidine incorporation was observed in large $B$ cells by high doses of IL-2 but not in small B cells. The response was dose-dependent and high concentrations of IL-2 were also required for proliferation, which was compatible with differentiation. These results taken together suggest that large low-density B cells, which are thought to be activated in vivo, express novel IL-2 binding molecules and may proliferate and differentiate through the interaction of IL-2 with them.

\section{Discussion}

Several previous studies showed that in vitro artificially activated $B$ cells expressed high-affinity IL-2R and physiological concentrations of IL-2 induced proliferation and differentiation through its interaction with high affinity IL-2R (14-17). It was also reported that high concentrations of IL-2 were required for differentiation of $B$ cells without Tac antigen expression $(18,19)$. It is controversial whether $B$ cells can express high affinity IL-2R in vivo and the role of IL- 2 in B cell differentiation remains unknown. In this regard, we demonstrated the existence of novel IL-2 binding molecules (p70, 75) in large low-density B cells, which are thought to be activated in vivo, but there was no detectable IL-2R in small B cells. IL-2 induced growth and Ig secretions in large $B$ cells, showing functional roles of IL-2 in B cell proliferation and differentiation.

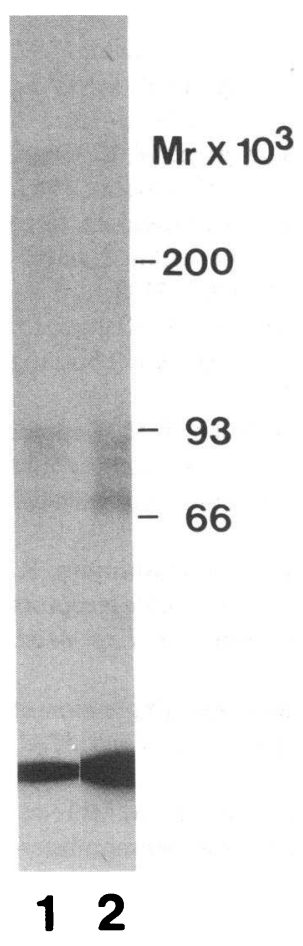

Figure 5. Induction of Tac antigen expression in large B cells by IL-2. Large low density $B$ cells were incubated in the absence of IL-2 ( $2 \mathrm{nM})$ (lane 1$)$ or presence of IL-2 (lane 2) for $2 \mathrm{~d}$, washed extensively, incubated for $4 \mathrm{~h}$ at $37^{\circ} \mathrm{C}$ and affinity crosslinking by using ${ }^{125} \mathrm{I}-\mathrm{IL}-2$ ( 10 nM) was carried out.
Table II. Proliferation of Human B Cells by IL-2

\begin{tabular}{cll}
\hline & \multicolumn{2}{c}{$\left[{ }^{3} \mathrm{H}\right]$ Thymidine uptake } \\
\cline { 2 - 3 } $\mathrm{IL-2}$ & Small B cells & \multicolumn{1}{c}{ Large B cells } \\
\hline$U / m l$ & & \\
0 & $513 \pm 45$ & $11,732 \pm 478$ \\
1 & $500 \pm 27$ & $10,600 \pm 1,074$ \\
10 & $550 \pm 34$ & $11,274 \pm 296$ \\
$10^{2}$ & $482 \pm 49$ & $12,087 \pm 2,376$ \\
$10^{3}$ & $490 \pm 3$ & $25,265 \pm 1,054$ \\
$10^{4}$ & $506 \pm 109$ & $35,603 \pm 2,308$ \\
\hline
\end{tabular}

Cells $\left(10^{5} /\right.$ well $)$ were incubated with IL- 2 for $3 \mathrm{~d}$. $\left[{ }^{3} \mathrm{H}\right]$ Thymidine $(0.4 \mu \mathrm{Ci} /$ well $)$ was added for the last $6 \mathrm{~h}$. Cells were harvested and washed on glass filters and $\left[{ }^{3} \mathrm{H}\right]$ thymidine incorporation was measured in a liquid scintillation counter. A representative result of three experiments is shown as expressed as geometric mean \pm SEM.

High concentrations of IL-2 were required for this induction due to intermediate affinity $\left(K_{\mathrm{d}}=1-3 \mathrm{nM}\right)$ of novel IL-2 binding molecules. Because it is unknown at present that high IL-2 concentrations may occur locally in vivo, it is not clear whether IL-2 has an important role in large B cell differentiation in vivo. However, two out of seven experiments revealed that some large B cells expressed Tac antigen in addition to p70, 75 and differentiated into Ig secreting cells by low doses of IL-2 through high affinity IL-2R. Moreover, IL-2 induced Tac antigen expression via p70, 75 in large $B$ cells, resulting in the expression of high affinity IL-2R. These phenomena show that in some host immune condition, large B cells can express high affinity IL-2R and it is possible that IL-2 induces Ig productions in these cells in vivo. A question, whether B cell differentiation by IL-2 is mediated through p70, 75 or high affinity IL-2R are required for it, is raised from these observations. We consider that the existence of $p 70,75$ is enough for $B$ cells to differentiate without Tac antigen expression in large $B$ cells but that high affinity IL-2R makes B cell differentiation more efficiently, supporting the following results. First, large B cells without detectable high affinity IL-2R at the initiation of the cultures were induced as much Ig productions in the absence of $\mathrm{H}-31$ as those in the presence of H-31. Secondly, SKW6-4 cells, in which IL-2 could not induce Tac antigen expression, were differentiated into IgM secreting cells through the interaction of IL-2 with p70, 75 molecules, suggesting that Tac antigen is not necessary for B cell differentiation directly. Highly purified B cells from tonsils are previously reported to differentiate into Ig secreting cells by IL-2 $(19,24)$. Romagnani et al. showed that IL-2-reactive B cells were mainly large activated $B$ cells, and no significant Ig secretion by IL-2 was observed in peripheral blood B cells, which contained a lower number of in vivo activated B cells than from tonsils (24). On the other hand, Bich-Thuy et al. reported that small as well as large B cells from tonsils, which had few detectable Tac antigen, were differentiated into Ig secreting cells by high concentrations of IL-2 (19). In the present study small high-density B cells were not differentiated into Ig secreting cells by IL-2 and expressed no detectable IL-2R. We can not explain the difference between the previous study and our results at present.

These studies may suggest direct effects of IL-2 on B cell. Contaminating $\mathrm{T}$ cells in B cell populations were negligible 
functionally and phenotypically, but we can not exclude the possibility that B cell differentiation by IL-2 was due to indirect effects of contaminating $\mathrm{T}$ cells or lymphokines derived from $T$ cells. Therefore, we examined whether monoclonal B cell lines expressed IL-2 binding molecules. IL- 2 binding and affinity crosslinking study revealed that some B cell lines expressed p70 and p75 and IL-2 functioned through its interaction with these molecules and suggest that the expression of p70, p75 was correlated with B cell maturation. With regard to responsive to IL-2, we can classify them into two groups. One group includes cell lines that are reactive to IL-2 (SKW6-4 and ARH-77) and the other includes cell lines that are unresponsive to IL-2 (U266, RPMI 8866, and CESS) irrespective of the existence of p70 and p75. We can consider some possibilities for the explanation in this phenomenon. First, simply cell stages may account for the difference. Secondly, it may be due to p70, 75 molecules by themselves, but precise characterization of them such as amino acid analysis remains unknown at present. Thirdly, postreceptor defects may exist in U266, RPMI 8866, and CESS. We examined whether IL-2 bound to p70, 75 was rapidly internalized or not. In unresponsive cell lines, the internalization of IL-2 occurred and the kinetic pattern of the internalization was similar to that in responsive cell lines. It is reported that IL-2 produces a rapid and transient redistribution of protein kinase $\mathrm{C}(\mathrm{PK}-\mathrm{C})$ from the cytosol to the plasma membrane in $\mathrm{T}$ cells and the activation of PK-C seems to have a crucial role in signal transduction of IL-2 (25). In preliminary experiments, phorbol myristate acetate (PMA) $(0.1-10 \mathrm{ng} / \mathrm{ml})$, an activator of PK-C transposition, induced $\mathrm{Ig}$ productions in both SKW6-4 and CESS cells. Moreover, synergistic or additive effects between IL-2 and PMA were not recognized at the maximal response by each stimulus but additive effects between them at suboptimal doses were observed in SKW6-4 cells, suggesting that activation of PK-C may play an important role in B cell differentiation by IL-2 and the third hypothesis seems likely. Further studies are necessary to evaluate the difference.

Freshly isolated unstimulated peripheral blood $\mathrm{T}$ cells and NK cells are reported to express p70, 75 but not Tac antigen and to respond to high concentrations of $\operatorname{IL}-2(8,11,12,26)$. In our crosslinking and IL-2 binding studies, $T$ cells stimulated by PHA displayed more p70, 75 than nonstimulated $\mathrm{T}$ cells suggesting that these molecules are also induced in activated $\mathrm{T}$ cells.

These results taken together have demonstrated that IL-2 directly induces Ig secretion in B cells through p70, 75 and p70, 75 may be expressed in association with $B$ cell differentiation. We hope that these findings should be helpful in the analysis of abnormalities in B cells of immunodeficient patients and be applicable to the therapy by IL-2. In fact, Weyand et al. reported that administration in vivo of high doses of IL-2 to mice induced a polyclonal IgM response (but not IgG), probably through their direct effects on B cells and that mice pretreated with IL-2 were protected from septic death, caused with $E$. coli $(27,28)$.

\section{Acknowledgments}

We would like to thank T. Kishimoto and T. Hirano for providing rBSF2, K. Sugamura for monoclonal antibody H-31, and Takeda Pharmaceutrical Co. for rIL-2 and J. Nagami for excellent secretarial assistance.
This work was supported by grants from the Ministry of Education, Science and Culture, the Ministry of Health and Welfare of Japan.

\section{References}

1. Morgan, D. A., F. W. Ruscetti, and R. Gallo. 1976. Selective in vitro growth of $\mathrm{T}$ lymphocytes from human bone marrows. Science (Wash. DC). 193:1007-1008.

2. Gillis, S., and K. A. Smith. 1977. Long term culture of tumourspecific cytotoxic T cells. Nature (Lond.). 268:154-156.

3. Henny, C. S., K. Kuribayashi, D. E. Kern, and S. Gillis. 1981. Interleukin 2 augments natural killer activity. Nature (Lond.). 291:335-338.

4. Sharon, M., R. D. Klasner, B. R. Cullen, R. Chizzonite, and W. J. Leonald. 1986. Novel interleukin-2 receptor subunit detected by crosslinking under high-affinity conditions. Science (Wash. DC). 234:859-863.

5. Teshigawara, K., H-M. Wang, K. Kato, and K. A. Smith. 1987. Interleukin 2 high-affinity receptor expression requires two distinct binding proteins. J. Exp. Med. 165:223-238.

6. Tsudo, M., R. W. Kozak, C. K. Goldman, and T. A. Waldmann. 1986. Demonstration of a non-Tac peptide that binds interleukin 2: A potential participant in a multichain interleukin 2 receptor complex. Proc. Natl. Acad. Sci. USA. 84:9694-9698.

7. Robb, R. J., C. M. Rusk, J. Yodoi, and W. C. Greene. 1987. Interleukin 2 binding molecule distinct from the Tac protein: Analysis of its role in formation of high affinity receptors. Proc. Natl. Acad. Sci. USA. 84:2002-2006.

8. Dukovich, M., Y. Wano, L. B. Thuy, P. Katz, B. R. Cullen, J. H. Kehrl, and W. C. Greene. 1987. A second human interleukin-2 binding protein that may be a component of high-affinity interleukin-2 receptors. Nature (Lond.). 327:518-522.

9. Robb, R. J., and W. C. Greene. 1987. Internalization of interleukin 2 is mediated by the $\beta$ chain of the high-affinity interleukin 2 receptor. J. Exp. Med. 165:1201-1206.

10. Bich-Thuy, L., M. Dukovich, N. J. Peffer, A. S. Fauci, J. H. Kehrl, and W. C. Greene. 1987. Direct activation of human resting T cells by IL-2: The role of an IL 2 receptor distinct from the Tac protein. J. Immunol. 139:1550-1556.

11. Siegel, J. P., M. Sharon, P. L. Smith, and W. J. Leonald. 1987. The IL-2 receptor $\beta$ chain ( $p 70$ ). Role in mediating signals for LAK, NK, and proliferative activities. Science (Wash. DC). 238:75-78.

12. Tsudo, M., C. K. Goldman, K. F. Bongiovanni, W. C. Chan, E. F. Winton, M. Yagita, E. A. Grimm, and T. A. Waldmann. 1987. The $\mathrm{p} 75$ peptide is the receptor for interleukin 2 expressed on large granular lymphocytes and is responsible for the interleukin 2 activation of these cells. Proc. Natl. Acad. Sci. USA. 84:5394-5398.

13. Tanaka, T., O. Saiki, S. Doi, S. Negoro, and S. Kishimoto. 1988. Interleukin 2 does function through novel interleukin 2 binding molecules in T cells. J. Immunol. 140:470-473.

14. Waldmann, T. A., C. K. Goldman, R. J. Robb, J. M. Depper, W. J. Leonald, S. O. Sharrow, K. F. Bongiovanni, S. J. Korsmeyer, and W. C. Greene. 1984. Expression of interleukin 2 receptors on activated human B cells. J. Exp. Med. 160:1450-1466.

15. Zubler, R. H., J. W. Lowenthal, F. Erand, N. Hashimoto, R. Devos, and H. R. Macdonald. 1984. Activated B cells express receptors for, and proliferate in response to, pure interleukin 2. J. Exp. Med. 160:1170-1183.

16. Tsudo, M., T. Uchiyama, and H. Uchino. 1984. Expression of Tac antigen on activated normal human B cells. J. Exp. Med. 160:612-617.

17. Mingari, M. C., F. Gerrosa, G. Carra, R. S. Accola, A. Moretta, R. H. Zubler, T., A. Waldmann, and L. Moretta. 1984. Human interleukin-2 promotes proliferation of activated B cells via surface receptors similar to those of activated T cells. Nature (Lond.). 312:641-643. 
18. Ralph, P., G. Jeong, K. Welte, R. Mertelsmann, H. Rabin, L. E. Henderson, L. M. Souza, T. C. Boone, and R. J. Robb. 1984. Stimulation of immunoglobulin secretion in human B lymphocytes as a direct effect of high concentrations of IL-2. J. Immunol. 133:2442-2445.

19. Bich-Thuy, L., and A. S. Fauci. 1985. Direct effect of interleukin 2 on the differentiation of human B cells which have not been preactivated in vitro. Eur. J. Immunol. 15:1075-1079.

20. Nakagawa, T., T. Hirano, N. Nakagawa, K. Yoshizaki, and T. Kishimoto. 1985. Effect of recombinant IL 2 and $\gamma$-IFN on proliferation and differentiation of human B cells. J. Immunol. 134:959-966.

21. Fujii, M., K. Sugamura, K. Sano, M. Nakai, K. Sugita, and Y. Hinuma. 1986. High affinity receptor-mediated internalization and degradation of interleukin 2 in human T cells. J. Exp. Med. 163:550 562 .

22. Goldsmith, P. K. 1981. A highly sensitive enzyme-linked immunosorbent assay for human immunoglobulin E: comparison of microtiter plate and disk methodologies. Anal. Biochem. 117:53-60.

23. Tanaka, T., O. Saiki, S. Doi, M. Hatakeyama, T. Doi, T. Kono, H. Mori, M. Fujii, K. Sugamura, S. Negoro, T. Taniguchi, and S.
Kishimoto. 1987. Functional interleukin 2 receptors in B cells lacking Tac antigen. Eur. J. Immunol. 17:1379-82.

24. Romagnani, S., G. Prete, M. G. Gindizi, R. Biagiotti, F. Almerigogna, A. Tiri, A. Alessi, M. Mazzetti, and M. Ricci. 1986. Direct induction of human B-cells differentiation by recombinant interleukin-2. Immunology. 58:31-35.

25. Farrar, W. L., and W. B. Anderson. 1985. Interleukin-2 stimulates association of protein kinase $\mathrm{C}$ with plasma membrane. Nature (Lond.). 315:233-235.

26. Bich-Thuy, L., H. C. Lane, and A. S. Fauci. 1986. Recombinant interleukin-2 induced polyclonal proliferation of in vitro unstimulated human peripheral blood lymphocytes. Cell. Immunol. 98:396410.

27. Weyand, C. M., J. Goronzy, M. J. Dallman, and C. G. Fathman. 1986. Administration of recombinant interleukin-2 in vivo induces a polyclonal IgM response. J. Exp. Med. 163:1607-1612.

28. Weyand, C. M., J. Goronzy, C. G. Fathman, and P. O'Hanley. 1987. Administration in vivo of recombinant interleukin 2 protects mice against septic death. J. Clin. Invest. 79:1756-1763. 